
\title{
$\begin{array}{ll}\text { Research Square } & \begin{array}{l}\text { Preprints are preliminary reports that have not undergone peer review. } \\ \text { They should not be considered conclusive, used to inform clinical practice, } \\ \text { or referenced by the media as validated information. }\end{array}\end{array}$
}

\section{Challenges of Health Care Reforms (HCRS) in Low and Middle-Income Countries (LMICs): A Qualitative Systematic Review}

Farbod Ebadi FardAzar

Iran University of Medical Sciences: Tehran University of Medical Sciences

Azam Choopani ( $\sim$ choopani.az@iums.ac.ir)

Iran University of Medical Sciences: Tehran University of Medical Sciences https://orcid.org/0000-0002-0262-1690

Seyed Ahmad Ahmadi Teymourlouy

Iran University of Medical Sciences: Tehran University of Medical Sciences

Seyed Hasan Arkian

Iran University of Medical Sciences: Tehran University of Medical Sciences

\section{Research}

Keywords: Healthcare reform, Low and Middle-income Countries, Health System Functions

Posted Date: May 13th, 2021

DOl: https://doi.org/10.21203/rs.3.rs-510547/v1

License: @ (i) This work is licensed under a Creative Commons Attribution 4.0 International License. Read Full License 


\section{Abstract}

Background: Healthcare reforms (HCRs) are performed by many resource-limited countries to improve the quality of health care. However, reforms do not always lead to the expected benefits and implementation problems are not fully considered due to lack of a systematic analysis of HCRs in these countries. Thus, the present study aimed to review the challenges of health care reforms in low and middle-income countries systematically.

Method: A systematic review of qualitative studies was used in the present study. Data were searched in five databases. The references related to the selected articles were searched for any relevant study irrespective of gray literature. The articles were screened based on PRISMA. The duplicates were removed, others were screened based on the title and abstract, and the eligible ones were selected for full-text reading and those matched with inclusion and exclusion criteria were selected for review. Framework analyses were used for data analysis, and the quality of the studies was evaluated by the CASP checklist for qualitative studies.

Results: 702 articles were found, among which 149 were duplicated, 553 were selected to primary screening, 390 were excluded, and 163 were selected for full text reading. Finally, 151 articles were excluded, and 12 matched with the inclusion and exclusion criteria were included in the study.

\section{Conclusion:}

Health reforms in low and middle-income countries have faced different challenges in financing, human resources, drugs and medicine, infrastructures, and governance, which can be influenced the delivery of qualified services. Thus, in order to design and implement any health care reforms in these countries, it is recommended for policymakers to take appropriate decisions about agenda setting, regulations and guidelines, sustainability of financing resources, collaborations, accountabilities and responsibilities, as well as the way of providing human resources, infrastructures, needed drugs, and medicine. In addition, the way of accessing services in rural and remote areas should be clarified. Finally, the reforms should be made very intelligently to direct the funds for the right needs and priorities in the countries where the donors' interests may be affected.

\section{Background}

Health care reforms (HCRs) provide a set of political actions for covering the four functions of the health systems including service delivery, stewardship or governance, financing, and resource generation in order to improve the performance of the health system and the health status of the population (1).

HCRs are considered as complex activities, and organizations and stakeholders usually resist against the changes due to the difference in values, benefits, political philosophy, and responsibility. In addition, the behavior of the health systems is not easily controllable because of its intrinsic complexity, and many health reforms fail due to insufficient preparation, lack of pilot studies, and insistence of pressure groups (2).

However, many developing countries have started the HCRs for accessing the broad health care and reduction in costs despite limited resources (3). However, it is very mixed and dispersed in these countries, and achieving the objectives of reforms has often been very disappointing. Regarding the reasons, poor designing and fast implementation of reforms for responding to economic and political changes outside the health system are highlighted (2). For example, the range of HCRs in the developing countries is very different in response to decentralization programs or imposing public sector reforms (4). Further, since there are no systematically analyses of health care reforms in the developing countries, these reform efforts do not always lead to expected benefits and implementation problems are not fully considered (2). Some studies indicated that healthcare reforms, especially in low and middle-income countries (LMICS), have face some challenges in financing and sustainability of financing resources, accessing to remote and rural areas, and providing needed human resources (5-12) Therefore, the present study aimed to review the challenges of health care in LMICs systematically.

\section{Methods}

\section{Eligibility criteria}

The present study aimed to evaluate the perspective of the health system key informants and experts in the LMICs about "HCRs" challenges. Therefore, the qualitative studies, which used the interview as one of the data collection instruments, were selected. To this aim, those studies searched from March to August 2019, and the remainder were considered in some databases such as PubMed for new articles. In addition, those articles published from 2000 onwards were considered for the purpose of this study since the health system functions introduced by WHO in 2000 were selected as the framework for analysis,.

thus, those studies written in English language, had at least one interview group, were published in 2000 onwards, and those were conducted in one of the LMICs based on World Bank classification(13) were considered as inclusion criteria. The studies which were conducted in high-income countries, as well as those related to letter to editors, comments, and suggestions and reviews, were excluded in the present study.

Search:

The studies searched in PubMed (Medline), Web of Knowledge, Cochrane Library, Scopus and WHO websites and used words and mesh terms such as Health Care Reform, Healthcare Reform, national health policy, and health care policy in combination with Healthcare Financing, Health Financing, Delivery of Healthcare, Healthcare Delivery, Resource, Governance, Stewardship, and the names of LMICs as their titles or abstracts were considered for the purpose of this study. The references of the selected articles searched for any relevant studies but gray literature was excluded in this study.

\section{Data collection method}


The articles which were potentially eligible to be included in the present study were imported to Endnote $\mathrm{X} 8$, and the duplicates were excluded based on PRISMA (14) checklist. Then, others were screened base on the titles and abstracts. Further, the selected articles were considered for full-text reading, and those matching with inclusion and exclusion criteria were selected for reviewing. Finally, the framework analyses were used for data analysis.

\section{Data collection process}

The data were obtained from general and specific information. First, titles, first authors, years of publication and countries were considered. Then, the objectives, data collection method, sample size, and the like were extracted. In order to validate the data, searching strategy was confirmed with one expert in librarianship, and data extraction forms were designed by reviewing several data extraction form and experts' opinions in systematic review workshops. Regarding the reliability of the collected data, two researchers (Ch A, A A) coded the data independently and disagreements were resolved by consensus (Ch A, A A). Finally, the quality the studies was evaluated by using the CASP (15) checklist for qualitative studies.

\section{Results}

\section{Study selection:}

First, 702 articles were extracted after searching in databases and other resources, among which 149 were duplicated, 553 were selected to primary screening in terms of their titles and abstracts, 390 were excluded, and 163 were selected for full-text assessment. Finally, 151 articles were excluded and 12 matching with inclusion and exclusion criteria were considered for the purpose of this study.

\section{Study characteristics}

The studies included in the review used the interview as one of the data collection methods. In total, the results of 667 interviews from 12 articles were examined in this review. Interview groups included health system top managers, supervisors, stockholders, health workers, users, policymakers, professionals, etc. The studies entered in the review were related to health system governance, mental health integration in PHC, user fees, maternity health, communitybased services, hospital management, health system strengthening, and decentralization and family nurses. Further, qualitative, cross-sectional descriptive, multi-method situation appraisal, and multiple-case study were considered as the methods used in these studies, and data collection methods were the combination of interview, document reviews, questionnaire, focus group discussion, and observation, among which interview was common in all of these studies. Finally, thematic analysis, framework analysis, and estimating the relationship were used for data analysis $($ Table 1,2$)$

\section{Risk of bias in different studies}

Among the 12 articles, six were conducted in South Africa, Tanzania, and Nepal which can influence the results. In addition, two of the articles were in health system governance which can increase the precision in this area.

\section{Synthesis of results}

In order to analyze the data, framework analysis was used. Framework analysis is considered as one of the analysis methods in qualitative studies. In this study, Gale et al.'s method

was utilized for data analysis. First, two researchers ( $\mathrm{CH} \mathrm{A}, \mathrm{A}$ A) read the articles for several times in order to be familiarized with the themes. Then, the data were coded independently in order to extract the related codes. Finally, 136 codes were obtained. In the next step, the framework of health system functions introduced by WHO in 2000 was used. In this framework, the functions of the health system were divided into financing, resource generation, stewardship (governance), and service delivery. Furthermore, the data were categorized into 25 subthemes. Finally, the matrix was developed and the data were interpreted (Table 2).

\section{Discussion}

LMICs are facing many challenges in designing and implementing the "HCRs". The present study evaluated these challenges in financing, resource generation, and governance (stewardship) which affected the delivery of qualified health services.

\section{Health financing challenges}

Based on the results, lack of providing sustainable and adequate funding is considered as one of the most important challenges in HCR financing among LMICs. In fact, HCRs have some challenges in providing adequate budgets such as allocation of a special amount in the budget plan, delay in receiving the budgets, high debts, budget deficit of hospitals, and the problems related to traditional budgeting systems. In addition, some other studies performed in Iran, Peru, Lithuania, Moldavia, and Brazil reported these challenges. Thus, it seems that providing sustainable and continuing fiscal resources can be considered as one of the strategies for succeeding the "HCRS" in these countries (7,13-26,30-32).

Further, inequity in resource allocation among different regions is regarded as another challenge in HCR financing among LMICs, which is increasing due to lack of transparency in guidelines, impact of donor's interests, and existence of competing priorities. However, some studies conducted in Armenia and Moldavia reported an improvement in equity in financing and directing the budgets received from donors $(8,33)$. Thus, the health system policymakers and 
managers in LMICs should direct the donor's interests for considering appropriate priorities and setting the clear guidelines and regulations for financial resources management.

\section{Challenges in resource generation}

The challenges related to resource generation are divided into human resources, infrastructures, and drug and instrument challenges.

\section{Human resource challenges}

Lack of adequate health workforce (HW) which is exaggerated in rural and remote areas is considered as one of the main challenges in human resources. In this regard, the studies conducted in Lithuania and Moldavia reported the shortage of health HW as a challenge in health system reforms $(8,26)$.

Other challenges are related to lack of motivation, skills, training HW, and structural and legal problems. In addition, some factors such as lack of understanding the skills and abilities by managers, weakness in career management systems, lack of training and high workload, using staffs in positions other than their organizational posts, poor monitoring, and evaluation systems, lack of compensating the weekend and holidays, low salaries, high staff turnover, and ensuring staff safety during night shifts can influence the motivation of HW, which result in increasing frequent absence, leaving the organization by trained staffs, remaining the inexperienced and low skilled staffs, and making concerns about quality of services. Additionally, structural and legal problems like absence or lack of organizational posts, problems in providing budgets for the existing posts and bureaucracy in the recruitment process can create some problems in HW recruitment. In addition, some studies indicated the challenges in providing needed HW in rural and remote areas, high turnover of HW, limited resources for developing the success experiences, and concerns about training $(7,8,26,28,32,34-37)$

\section{Challenges in infrastructures and drugs}

Based on the results, physical space, equipment, and drugs are considered as other major challenges in resource generation are. Based on the results, the countries coped with some problems and challenges in providing needed physical space for delivering privacy service, lacking drug, delaying in providing drugs, emptying drug stores, increasing service recipients, increasing demands, centralizing drug providing and distribution system, and lacking access to guidelines in some countries. Further, some conflicts were reported between providers and recipients due to lack of medicines and drugs. Finally, Manyazavil et al. enumerated a shortage of drugs, medical equipment, and instrument as one of the major challenges in hospital reforms (1).

\section{Governance challenges}

Based on the results, many governance challenges in HCRs among LMICs based on Siddigi et al.'s(38) framework were divided into the rule of low, strategic direction, responsibilities, collaboration, efficiency, and effectiveness, ethics, equity and comprehensiveness, transparency and information.

In addition, changing the structures based on political motives instead of real needs, lack of enough legal requirement, inappropriate process for decentralization, lack of clarity in roles and tasks, resistance to implementing guidelines with lack of understanding the reform process by managers, as well as lack of clear guidelines and training resulted in confusing executive units and different interpretations by stockholders, blocking the accountability and responsibility due to the creation of levels of double or multiple accountabilities, and accordingly destroying the trust between the provider and recipient, as well as inter-sectorial and multi-sectoral collaborations.

Further, poor monitoring and evaluation systems such as lack of a good mechanism for data monitoring and evaluating human resource performance was regarded as other challenges in HCRs among LMICs.

Furthermore, the disparity between regions in terms of facilities, HR, infrastructure capacity, and budget increased equity and comprehensiveness problems. Additionally, lack of availability of guidelines on time and an increase in informal payments in some countries are considered as ethical challenges.

Other studies highlighted lack of planning and coordination, lack of management capacity for managerial reforms, gaps in technical skills, lack of trusted performance evaluation system and resistance in change $(27,39-40)$.

In addition, lack of collaboration and rules, transparency and accountability in resource distribution, and social and economic inequality were considered as some of the reform challenges in Lithuania and South Africa $(26,41)$. In China, equity in outcomes and distribution of public resources in the regions were regarded as some challenges in monitoring and evaluation systems, which influenced the governance of reforming health services (42). Cherry et al. indicated that health care reforms faced many challenges and the main challenge is related to an increase in efficiency and effectiveness of available services (43).

Lawrence outlined three major challenges for "HCRs". Reforms should be conducted in both public and private system agendas. The second challenges are related to the acceptable and appropriate division of work between actors and key organizations. Finally, a reform model, which is very reliable and politically attractive, should be highlighted (44).

Finally, regarding Brazil's health care reform, the sustainability of reform, monitoring, and evaluation, and problems in quality, and effectiveness of healthcare, which caused largely due to deficiencies in guidelines were regarded as some challenges (7).

\section{Health care delivery challenges}

The promotion of the people's health status is the main objective of the health system, which is responsible for delivering health services. However, inadequate resources or poor financing systems can create some weaknesses in this regard (45). Therefore, identifying the related challenges was considered as the main purpose of the present study. 
According to WHO, good service delivery should involve comprehensiveness, accessibility, appropriate coverage, continuity, quality, patient-centeredness, coordination, accountability, and efficiency (46). Based on the results, there are challenges in coverage and access, especially in rural and remote areas among LMICs $(47,48)$. Further, it seems that the continuity of reforms can be influenced by focusing on the unsustainability of financing resources, Furthermore, there are some concerns about the quality of the delivered services regarding the existing lack of skills, training, and motivation in health HW. Additionally, the donor's interests can affect the financing and kind of reforms and services in some countries since these services are not provided based on the needs. In addition, some studies reported the challenges related to inter-sectorial and multi-sectorial collaborations in these countries, as well as accountability and efficiency may influence service delivery. Finally, the studies conducted in Brazil, Armenia, Lithuania, Greece, China, Turkey, Moldavia, Iran, and Peru emphasized these challenges, which are consistent with the findings in the present study $(8,13-14,29-29,33-34)$.

\section{Conclusion}

It seems that health care reforms in LMICs face different challenges in financing, HW, drug and medicine, infrastructure and governance which influence the delivery of appropriate and qualified services. Thus, it is recommended for policymakers to make appropriate decisions about agenda setting, regulations, clear guidelines, sustainability of financial resources, collaborations, detailed roles and tasks of every stakeholder and decision on the way for providing HR, infrastructures, needed drugs, and medicine in order to design and implement any reform. In addition, how access to services in rural and remote areas should be clarified. Further, policymakers should be very alert to sign the funds for the right needs and priorities in the countries in which the interests of donors can affect the reforms. In other words, comprehensive assessments and evidence are required for implementing health reforms in LMICs. Thus, the road map of reform, tasks, and roles of stakeholders, as well as the process of delivering services, and accountabilities, responsibilities and at least executive and political quarantines should be clearly identified.

\section{Limitations}

In the present study, the studies written in English language were only considered for reviewing since limitations in translating skills could create some regional limitations, which may affect the results. Further, there were few studies which considered an interview for data collection. Finally, only electronic articles were considered for the purpose of this study. In fact, gray literature and non-published studies were ignored.

\section{Abbreviations}

"HCRs": Health Care Reforms

LMICs: Low and Middle-Income Countries

HR: Human Resources

CASP: Critical Appraisal Skills program

PRISMA: Preferred Reporting Items for Systematic Reviews and Meta-Analyses

HW: Health workforce

\section{Declarations}

Ethics approval and consent to participate: Not applicable

Consent for publication: Not applicable

Availability of data and materials: search strategy, PRISMA cheklist, CASP checklist and quality assessment of articles attached in supplimentary section.

Competing interests: The authors declare that they have no competing interests

Funding: Not funding, The present study was conducted as one of the requirements for Master degree in Public Health degree in Health Faculty of Iran University of Medical Sciences by code number 12773

\section{Authors' contributions:}

E F A F: contributed in Determining Research questaion, Writing search strategy, writing results, writing discussion, revising the article

Ch A: contributed in Determining Research question, Writing search strategy, Searching articles, Coding, Quality assess, Writing results, writing discussion, revising article

A A: contributed in Determining Research qustion, Writing search strategy, Searching articles, Coding, Quality assess

A S H: contributed in Searching articles, Quality assess, Writing results

Acknowledgments: We acknowledge persons that help us in writing the search strategy. 


\section{References}

1. Sein T. Evidence and Information for Policy, WHO-SEARO. Health sector reform issues and opportunities. REGIONAL OFFICE FOR SOUTH-EAST ASIA. 2000. 2000.

2. Jabbari Beyrami H. Desenterlization in the health system. Tabriz: Vice-chancellor for research, National Center for Health Management, Tabriz University of Medical Sciences; 2007. 180 p. 2007.[In persian].

3. Beyene W, Jira C, Sudhakar M. Assessment of quality of health care in Jimma zone, southwest Ethiopia. Ethiopian Journal of health sciences. 2011;21(3).

4. Lundberg M, Wang L, Coudouel A, Paternostro S. Health sector reforms. Analyzing the distributional impact of reforms. 2006:43-110.

5. Sampaio LFR. The Brazilian health system: highlighting the primary health care reform. Italian Journal of Public Health. 2012;7(4).

6. Turcanu G, Domente S, Buga M, Richardson E. Republic of Moldova health system review. Health Syst Transition. 2012;14(7):1-151.

7. Schneider H, Schaay N, Dudley L, Goliath C, Qukula T. The challenges of reshaping disease-specific and care-oriented community-based services towards comprehensive goals: a situation appraisal in the Western Cape Province, South Africa. BMC Health Serv Res. 2015;15:436.

8. Wamalwa EW. Implementation challenges of free maternity services policy in Kenya: The health workers' perspective. Pan African Medical Journal. 2015;22.

9. Mugisha J, Ssebunnya J, Kigozi FN. Towards understanding governance issues in integration of mental health into primary health care in Uganda. International journal of mental health systems. 2016;10(1).

10. Ferdosi M, Kabiri S, Keyvanara M, Yarmohammadian MH. Challenges of Iran Health Transformation Plan about Inpatients Payment: Viewpoint of Experts. Health Scope. 2017;6(3).

11. Mehralizadeh Y, Gilavand A, Alizadeh MS, Hajizadeh K. evaluation of the health system reform plan in Iranian universities of medical sciences in terms of community empowerment.Indo American. J Pharm Sci. 2017;4(12):4566-79.

12. Wu D, Lam TP, Lam KF, Zhou XD, Sun KS. Challenges to healthcare reform in China: profit-oriented medical practices, patients' choice of care and guanxi culture in Zhejiang province. Health policy planning. 2017;32(9):1241-7.

13. Bank W. 2019 [Available from Https://datahelpdesk.Worldbank.Org/knowledgebase/articles/906519-world-bank-country-and-lending-groups.

14. Gonçalves RW, Vieira FS, Delgado PGG. Mental health policy in Brazil: Federal expenditure evolution between 2001 and 2009. Rev Saude Publica. 2012;46(1):51-8.

15. critical appraisal skills program. 2019 [Available from https://casp-uk.net/casp-tools-checklists/.

16. Arredondo A, Orozco E, Recaman AL. Qualitative analysis of governance trends after health system reforms in Latin America: lessons from Mexico. Public Health. 2018;156:140-6.

17. Marais DL, Petersen I. Health system governance to support integrated mental health care in South Africa: challenges and opportunities. International journal of mental health systems. 2015;9:14.

18. Sato M, Gilson L. Exploring health facilities' experiences in implementing the free health-care policy (FHCP) in Nepal: how did organizational factors influence the implementation of the user-fee abolition policy? Health policy planning. 2015;30(10):1272-88.

19. Shwekerela B. The effects of hospital reforms on the management of public hospitals in Tanzania: Challenges and lessons learnt. World hospitals and health services. the official journal of the International Hospital Federation. 2014;50(4):23-6.

20. Risso-Gill I, McKee M, Coker R, Piot P, Legido-Quigley H. Health system strengthening in Myanmar during political reforms: perspectives from international agencies. Health policy planning. 2014;29(4):466-74.

21. Frumence G, Nyamhanga T, Mwangu M, Hurtig AK. Challenges to the implementation of health sector decentralization in Tanzania: experiences from Kongwa district council. Global health action. 2013;6:20983.

22. Dhakal R, Ratanawijitrasin S, Srithamrongsawat S. Addressing the challenges to health sector decentralization in Nepal: an inquiry into the policy and implementation processes. Nepal Medical College journal NMCJ. 2009;11(3):152-7.

23. Parfitt BA, Cornish F. Implementing Family Health Nursing in Tajikistan: from policy to practice in primary health care reform. Soc Sci Med. 2007;65(8):1720-9.

24. Murauskiene L, Janoniene R, Veniute M, van Ginneken E, Karanikolos M. Lithuania: health system review. Health Syst Transition. 2013;15(2):1-150.

25. Economou C, Kaitelidou D, Karanikolos M, Maresso A. Greece. Health System Review Health systems in transition. 2017;19(5):1-166.

26. Toyama M, Castillo H, Galea JT, Brandt LR, Mendoza M, Herrera V, et al. Peruvian Mental Health Reform: A Framework for Scaling-up Mental Health Services. International journal of health policy management. 2017;6(9):501-8.

27. Mahdavi M, Parsaeian M, Jaafaripooyan E, Ghaffari S. Recent Iranian health system reform: An operational perspective to improve health services quality. International Journal of Health Policy Management. 2018;7(1):70-4.

28. Ekman B, Liem NT, Duc HA, Axelson H. Health insurance reform in Vietnam: a review of recent developments and future challenges. Health policy planning. 2008;23(4):252-63.

29. Agustina R, Dartanto T, Sitompul R, Susiloretni KA, Suparmi, Achadi EL, et al. Universal health coverage in Indonesia: concept, progress, and challenges. Lancet. 2019;393(10166):75-102. 
30. Ahmedov M, Rechel B, Alimova V, Azimov R. Primary health care reform in Uzbekistan. The International Journal of health planning management. 2007;22(4):301-18.

31. Richardson E. Armenia: health system review. Health Syst Transition. 2013;15(4):1-99.

32. Agartan TI. Health workforce policy and Turkey's health care reform. Health Policy. 2015;119(12):1621-6.

33. Zhang M, Wang W, Millar R, Li G, Yan F. Coping and compromise: a qualitative study of how primary health care providers respond to health reform in China. Human resources for health. 2017;15(1):50.

34. Organization WH. Increasing access to health workers in remote and rural areas through improved retention 2010 [Available from https://www.who.int/hrh/retention/guidelines/en/.

35. Grundy J, Moodie R. An approach to health system strengthening in the Democratic Peoples Republic of Korea (North Korea). The International Journal of health planning management. 2009;24(2):113-29.

36. Manyazewal T, Oosthuizen MJ, Matlakala MC. Proposing evidence-based strategies to strengthen implementation of healthcare reform in resourcelimited settings: a summative analysis. BMJ Open. 2016;6(9):e012582.

37. Siddiqi S, Masud TI, Nishtar S, Peters DH, Sabri B, Bile KM, et al. Framework for assessing governance of the health system in developing countries: gateway to good governance. Health policy. (Amsterdam Netherlands). 2009;90(1):13-25.

38. Pervaiz F, Shaikh BT, Mazhar A. Role of development partners in Maternal, Newborn and Child Health (MNCH) programming in post-reform times: a qualitative study from Pakistan. BMJ Open. 2015;5(11):e008665.

39. Duran A, Kutzin J, Menabde N. Universal coverage challenges require health system approaches; the case of India. Health Policy. 2014;114(2-3):269-77.

40. Brooke-Sumner C, Lund C, Petersen I. Bridging the gap: Investigating challenges and way forward for intersectoral provision of psychosocial rehabilitation in South Africa. International journal of mental health systems. 2016;10(1).

41. Brixi H, Mu Y, Targa B, Hipgrave D. Engaging sub-national governments in addressing health equities: challenges and opportunities in China's health system reform. Health policy planning. 2013;28(8):809-24.

42. Iltis AS, Cherry MJ. First do no harm: critical analyses of the roads to health care reform. J Med Philos. 2008;33(5):403-15.

43. Brown LD. Political challenges for healthcare reform. PharmacoEconomics. 2006;24(Suppl 2):95-9.

44. WHO. The world health report2000: health system improving performance. 2000.

45. Organization WH. Monitoring the building blocks of health systems: a handbook of indicators and their measurement strategies. World Health Organization; 2010.

46. Yardim MS, Uner S. Equity in access to care in the era of health system reforms in Turkey. Health Policy. 2018;122(6):645-51.

47. Noh KM. Primary health care reform in 1CARE for 1 Malaysia. International Journal of Public Health Research Special Issue. 2011;2011:50-6.

\section{Tables}

Table 1:study characteristics 


\begin{tabular}{|c|c|c|c|c|c|c|c|c|c|}
\hline Year & Country & $\begin{array}{l}\text { Firs } \\
\text { another }\end{array}$ & Setting & $\begin{array}{l}\text { Study } \\
\text { design }\end{array}$ & $\begin{array}{l}\text { Sample } \\
\text { size }\end{array}$ & $\begin{array}{l}\text { Sampling } \\
\text { method }\end{array}$ & $\begin{array}{l}\text { Data } \\
\text { gathering } \\
\text { method }\end{array}$ & $\begin{array}{l}\text { Analyzing } \\
\text { method }\end{array}$ & Interview group \\
\hline 2018 & (18)Mexico & $\begin{array}{l}\text { A. } \\
\text { Arredondo }\end{array}$ & Governance & qualitative & 189 & purposively & $\begin{array}{l}\text { semi- } \\
\text { structured } \\
\text { interviews- } \\
\text { documents }\end{array}$ & $\begin{array}{l}\text { thematic } \\
\text { analysis }\end{array}$ & $\begin{array}{l}\text { Senior-level } \\
\text { managers } \\
\text { planning and } \\
\text { evaluation } \\
\text { directors, SPS } \\
\text { directors, and } \\
\text { directors of } \\
\text { decentralization. }\end{array}$ \\
\hline 2017 & (12)Iran & $\begin{array}{l}\text { Masoud } \\
\text { Ferdosi }\end{array}$ & $\begin{array}{l}\text { Inpatient } \\
\text { payment }\end{array}$ & qualitative & 20 & purposively & $\begin{array}{l}\text { semi- } \\
\text { structured } \\
\text { interview }\end{array}$ & $\begin{array}{l}\text { thematic } \\
\text { analyze }\end{array}$ & $\begin{array}{l}\text { Staff in different } \\
\text { wards of } \\
\text { covered } \\
\text { hospitals who } \\
\text { are } \\
\text { involved in the } \\
\text { plan } \\
\text { - Chief } \\
\text { executives of } \\
\text { the HTP at the } \\
\text { university level }\end{array}$ \\
\hline 2016 & (11)Uganda & $\begin{array}{l}\text { James } \\
\text { Mugisha }\end{array}$ & $\begin{array}{l}\text { integration of } \\
\text { mental health } \\
\text { into PHC }\end{array}$ & qualitative & 18 & purposively & Interview & $\begin{array}{l}\text { thematic } \\
\text { analysis }\end{array}$ & $\begin{array}{l}\text { Professionals } \\
\text { and senior } \\
\text { managers, with } \\
\text { more than } 5 \\
\text { years' } \\
\text { experience. The } \\
\text { senior } \\
\text { managers from } \\
\text { the Ministry of } \\
\text { Health } \\
\text { headquarters } \\
\text { were from the } \\
\text { mental health } \\
\text { unit, planning } \\
\text { and budgeting } \\
\text { departments. } \\
\text { Health program } \\
\text { managers, an } \\
\text { administrator, } \\
\text { and } \\
\text { health facility } \\
\text { managers. }\end{array}$ \\
\hline 2015 & Kenya(10) & $\begin{array}{l}\text { Emmanuel } \\
\text { Wekesa } \\
\text { Wamalwa }\end{array}$ & $\begin{array}{l}\text { maternity } \\
\text { services }\end{array}$ & $\begin{array}{l}\text { cross- } \\
\text { sectional } \\
\text { descriptive } \\
\text { study }\end{array}$ & 100 & Purposively & $\begin{array}{l}\text { Interview- } \\
\text { The } \\
\text { questionnaire }\end{array}$ & $\begin{array}{l}\text { Measuring } \\
\text { association }\end{array}$ & $\begin{array}{l}\text { Health workers } \\
\text { who are } \\
\text { involved in the } \\
\text { implementation } \\
\text { of the } \\
\text { policy.Doctors, } \\
\text { clinical officers, } \\
\text { and nurses. }\end{array}$ \\
\hline 2015 & $\begin{array}{l}\text { South } \\
\text { Africa(9) }\end{array}$ & $\begin{array}{l}\text { Helen } \\
\text { Schneider } \\
1\end{array}$ & $\begin{array}{l}\text { community } \\
\text { based services }\end{array}$ & $\begin{array}{l}\text { multi- } \\
\text { method } \\
\text { situation } \\
\text { appraisal }\end{array}$ & 97 & purposively & $\begin{array}{l}\text { semi- } \\
\text { structured } \\
\text { interviews or } \\
\text { focus group } \\
\text { discussions }\end{array}$ & $\begin{array}{l}\text { thematic } \\
\text { analysis }\end{array}$ & $\begin{array}{l}\text { Players } \\
\text { providing, } \\
\text { managing or } \\
\text { receiving CBS. }\end{array}$ \\
\hline 2015 & $\begin{array}{l}\text { South } \\
\text { Africa(19) }\end{array}$ & $\begin{array}{l}\text { Debra } \\
\text { Leigh } \\
\text { Marais }\end{array}$ & $\begin{array}{l}\text { integration of } \\
\text { mental health } \\
\text { into PHC }\end{array}$ & qualitative & 17 & $\begin{array}{l}\text { Purposive } \\
\text { sampling }\end{array}$ & $\begin{array}{l}\text { Semi- } \\
\text { structured } \\
\text { qualitative } \\
\text { interviews. }\end{array}$ & $\begin{array}{l}\text { Framework } \\
\text { analysis }\end{array}$ & $\begin{array}{l}\text { Policymakers at } \\
\text { the national } \\
\text { level in the } \\
\text { Department of } \\
\text { Health, } \\
\text { provincial } \\
\text { coordinators } \\
\text { and planners in } \\
\text { primary health } \\
\text { care and in } \\
\text { mental health, } \\
\text { and district } \\
\text { managers of } \\
\text { primary health } \\
\text { care and mental } \\
\text { health care } \\
\text { services. }\end{array}$ \\
\hline
\end{tabular}




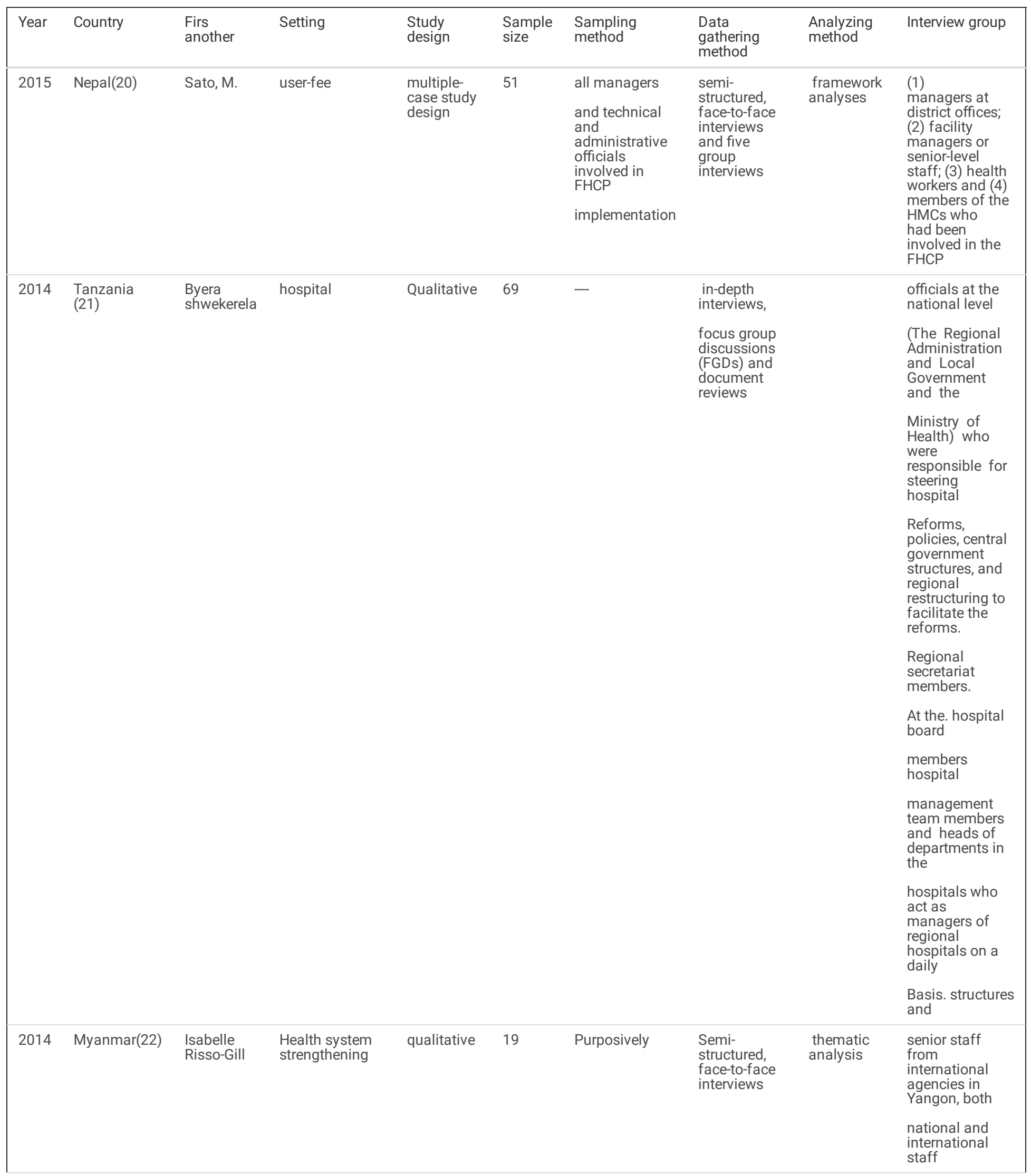




\begin{tabular}{|c|c|c|c|c|c|c|c|c|c|}
\hline Year & Country & $\begin{array}{l}\text { Firs } \\
\text { another }\end{array}$ & Setting & $\begin{array}{l}\text { Study } \\
\text { design }\end{array}$ & $\begin{array}{l}\text { Sample } \\
\text { size }\end{array}$ & $\begin{array}{l}\text { Sampling } \\
\text { method }\end{array}$ & $\begin{array}{l}\text { Data } \\
\text { gathering } \\
\text { method }\end{array}$ & $\begin{array}{l}\text { Analyzing } \\
\text { method }\end{array}$ & Interview group \\
\hline 2013 & $\begin{array}{l}\text { Tanzania } \\
(23)\end{array}$ & $\begin{array}{l}\text { Gasto } \\
\text { Frumence } \\
1\end{array}$ & Decentralization & qualitative & 23 & purposively & $\begin{array}{l}\text { interviews } \\
\text { with key } \\
\text { informants } \\
\text { and a review } \\
\text { of key } \\
\text { documents }\end{array}$ & $\begin{array}{l}\text { thematic } \\
\text { analytical }\end{array}$ & $\begin{array}{l}\text { Key } \\
\text { policymakers } \\
\text { and planners at } \\
\text { the national } \\
\text { level and health } \\
\text { officials and } \\
\text { key local } \\
\text { authority } \\
\text { officials from } \\
\text { the council level } \\
\text { senior } \\
\text { management } \\
\text { officials the } \\
\text { district } \\
\text { executive officer } \\
\text { (DED), the } \\
\text { district planning } \\
\text { officer (DPLO), } \\
\text { the district } \\
\text { treasurer } \\
\text { (DT), three } \\
\text { CHMT members } \\
\text { (district medical } \\
\text { officer, } \\
\text { district health } \\
\text { secretary, and } \\
\text { district health } \\
\text { officer), } \\
\text { the district AIDS } \\
\text { control program } \\
\text { coordinator, two } \\
\text { councilors, and } \\
\text { the person in } \\
\text { charge of the } \\
\text { health center }\end{array}$ \\
\hline 2009 & Nepal(24) & $\begin{array}{l}\text { R Dhakal, } \\
1\end{array}$ & $\begin{array}{l}\text { decentralization } \\
\text { policy } \\
\text { implementation }\end{array}$ & qualitative & 37 & & $\begin{array}{l}\text { In-depth } \\
\text { interviews, } \\
\text { focus group } \\
\text { discussion, } \\
\text { observation } \\
\text { literature, and } \\
\text { health } \\
\text { facilities } \\
\text { records } \\
\text { reviews. }\end{array}$ & & $\begin{array}{l}\text { Theoretical } \\
\text { relevance and } \\
\text { on their long } \\
\text { experience in } \\
\text { the health and } \\
\text { decentralization } \\
\text { process. }\end{array}$ \\
\hline 2007 & $\begin{array}{l}\text { Tajikistan } \\
(25)\end{array}$ & $\begin{array}{l}\text { Barbara } \\
\text { Ann Parfitt }\end{array}$ & $\begin{array}{l}\text { Family Health } \\
\text { Nursing }\end{array}$ & qualitative & 27 & $\begin{array}{l}\text { Random } \\
\text { sampling }\end{array}$ & $\begin{array}{l}\text { interviews- } \\
\text { focus } \\
\text { groups- } \\
\text { Observation }\end{array}$ & $\begin{array}{l}\text { Framework } \\
\text { analysis }\end{array}$ & $\begin{array}{l}\text { Family Health } \\
\text { Nurses, Family } \\
\text { Physicians, }\end{array}$ \\
\hline
\end{tabular}

Table 2:Study characteristics

\begin{tabular}{|c|c|c|c|c|c|c|c|c|c|}
\hline \multicolumn{2}{|l|}{ Country } & \multicolumn{2}{|l|}{ Reform type } & \multicolumn{2}{|l|}{ Data gathering tools } & \multicolumn{2}{|l|}{ Study type } & \multicolumn{2}{|c|}{$\begin{array}{l}\text { Data analyzing } \\
\text { method }\end{array}$} \\
\hline Mexico & 1 & Governance & 2 & $\begin{array}{l}\text { Interview- document } \\
\text { analysis }\end{array}$ & 3 & qualitative & 9 & $\begin{array}{l}\text { Thematic } \\
\text { analysis }\end{array}$ & 6 \\
\hline Iran & 1 & Inpatient payment & 1 & Interview & 4 & $\begin{array}{l}\text { multi-method } \\
\text { situation } \\
\text { appraisal }\end{array}$ & 1 & $\begin{array}{l}\text { Measuring } \\
\text { association }\end{array}$ & 1 \\
\hline Uganda & 1 & $\begin{array}{l}\text { Integrating mental } \\
\text { health in PHC }\end{array}$ & 2 & Interview- questionnaire & 1 & $\begin{array}{l}\text { multiple-case } \\
\text { study design }\end{array}$ & 1 & $\begin{array}{l}\text { Framework } \\
\text { analysis }\end{array}$ & 3 \\
\hline Kenya & 1 & Maternity health & 1 & $\begin{array}{l}\text { Interview- document } \\
\text { analysis- focus group } \\
\text { discussion }\end{array}$ & 3 & $\begin{array}{l}\text { cross-sectional } \\
\text { descriptive } \\
\text { study }\end{array}$ & 1 & $\begin{array}{l}\text { Not clearly } \\
\text { determined }\end{array}$ & 2 \\
\hline South Africa & 2 & $\begin{array}{l}\text { Community based } \\
\text { services }\end{array}$ & 1 & $\begin{array}{l}\text { Interview- - focus group } \\
\text { discussion- observation }\end{array}$ & 1 & & & & \\
\hline Nepal & 2 & hospitals & 1 & & & & & & \\
\hline Tanzania & 2 & $\begin{array}{l}\text { Health system } \\
\text { strengthening }\end{array}$ & 1 & & & & & & \\
\hline Myanmar & 1 & Decentralization & 2 & & & & & & \\
\hline Tajikistan & 1 & Family health nursing & 1 & & & & & & \\
\hline
\end{tabular}

Table 3: themes and subthemes extracted 


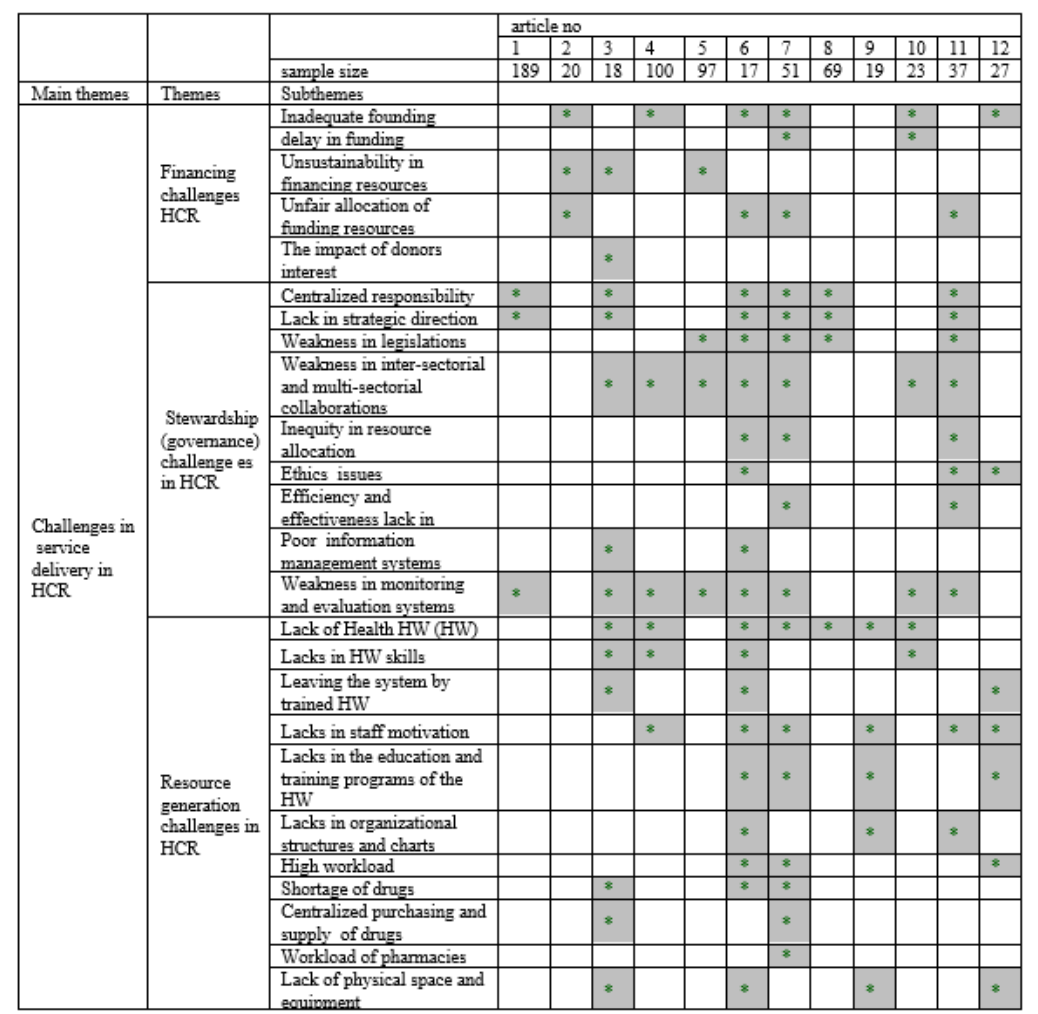

\section{Figures}
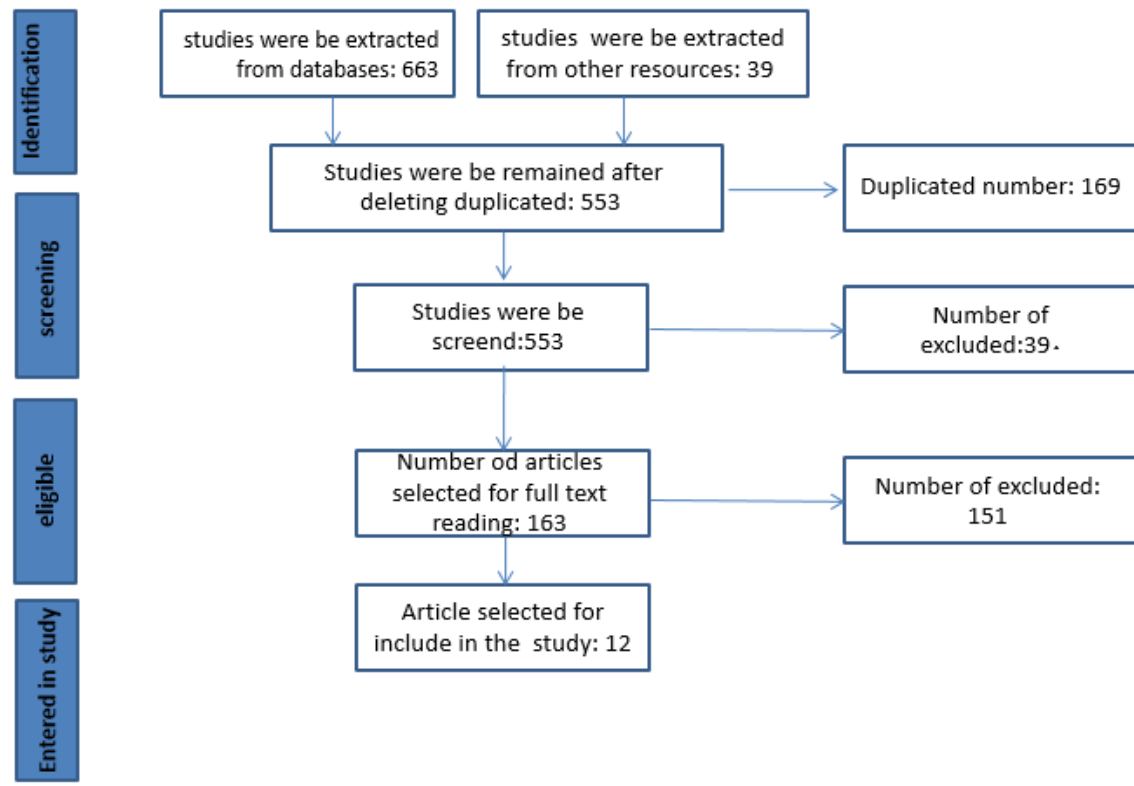

Article selected for

include in the study: 12

Figure 1

study selection process 